\title{
IMAGINAÇÃ̃, REALIDADE E POSSIBILIDADE NA FILOSOFIA DE SARTRE
}

\author{
Marcelo Prates ${ }^{1}$ \\ Universidade Estadual do Centro-Oeste ( UNICENTRO) \\ (D) https://orcid.org/0000-0001-5180-6053
}

\begin{abstract}
RESUMO:
Este artigo tem por objetivo analisar uma das críticas de Mészáros à Sartre, qual seja, a da determinação negativa da totalidade. Partindo da distinção entre real e irreal regressamos à discussão entre o real e o imaginário e indicamos um terceiro elemento, o possível, como tessitura do real. $\mathrm{O}$ possível afere ao real como um movimento e denota este enquanto totalização. Assim, sempre como processo e possibilidade, o real e o total são compreendidos segundo a liberdade própria do sujeito.
\end{abstract}

PALAVRAS-CHAVE: Sartre; Possível; Imaginação; Realidade.

\section{IMAGINATION, REALITY AND POSSIBILITY IN SARTRE'S PHILOSOPHY}

\begin{abstract}
:
This article aims to analyze one of Mészáros' criticisms of Sartre, that is, the negative determination of totality. Starting from the distinction between real and unreal, we return to the discussion between the real and the imaginary and indicate a third element, the possible, as the texture of the real. The possible characterizes the real as a movement and denotes this as a totalization. Thus, always as process and possibility, the real and the total are understood according to the freedom of the subject.
\end{abstract}

KEYWORDS: Sartre; Possible; Imagination; Reality.

\footnotetext{
1 Doutor em Filosofia. Professor substituto da Universidade Estadual do Centro-Oeste (UNICENTRO), Paraná - Brasil. E-mail: marceloprates1@gmail.com
}

PRATES, Marcelo. Imaginação, realidade e possibilidade na filosofia de Sartre. Griot : Revista de Filosofia, Amargosa/Bahia, v.17, n.1, p.154-176, junho/2018. 
Em um momento de sua obra sobre Sartre, aquele onde procura analisar a relação entre o indivíduo e a totalidade, István Mészáros tece três grandes críticas a esta filosofia. Na segunda delas o ponto discutido é a "determinação negativa da totalidade" (2012, p. 110). Ora, sabe-se que a fenomenologia de Sartre toma como ponto de partida o homem concreto enquanto totalidade homem-no-mundo (EN, p.37). A partir desse mote, a totalidade é sempre um horizonte perseguido pela metodologia da filosofia de Sartre. Não obstante, os leitores de Sartre sabem da sua rejeição a uma totalidade fechada, e mesmo nas variações que sua filosofia possa ter sofrido, é certo que a ideia de totalização passa a se sobrepor a de nadificação, sobretudo a partir da Crítica da razão dialética (BORNHEIM, 2003, p. 253). Nesse caso, Sartre sempre coloca a realidade como essa totalização constante, mas jamais fechada ou estática, pois se a existência é espontaneidade e explosão no ser, ela não o é apenas por uma origem ou um ato primeiro, mas por um movimento constante. Nesse caso, a totalidade seria apenas um horizonte fenomenológico e limitativo dada a percepção atual e a consciência atual, uma vez que o fenômeno é limitado por si mesmo e afere à sua finitude. Mas a existência mesma seria esse processo totalizador constante e a História a totalização dessas totalizações sem totalizador (CRD, p. 158).

Entretanto, ao ver o pensamento de Sartre como a "dedução de uma filosofia moral socialmente orientada a partir da estrutura ontológica da práxis individual" (MÉSZÁROS, 2012, p. 68) Mészáros insistentemente procura observar e enfatizar as condições críticas da estrutura da totalidade. Entre as diversas críticas que traça sobre a obra de Sartre, nas três principais dirigidas no capítulo quatro de seu texto, ele aponta que a consideração da negatividade seria tomada por algumas aplicações de Sartre de certos princípios heideggerianos à análise do imaginário (MÉSZÁROS, 2012, p. 110). A ênfase que Mézsáros dá naquele ponto é a de que, embora a consciência seja ontologicamente dada no mundo, seria impossível para ela a criação imaginária caso ela não pudesse escapar a este mesmo mundo, portanto, ela precisa ser livre. Assim, o desmoronamento do mundo só poderia ser possível se a própria consciência fosse a responsável, em seu processo nadificador, pela totalização do mundo enquanto mundo. Ora, assim sendo, como traz o próprio Mészáros pelas palavras de Sartre em $O$ imaginário "o deslizamento do mundo no seio do nada e a emergência da realidade humana no mesmo nada só podem efetuar-se pela posição de alguma coisa que é nada em relação ao mundo e em relação à qual o mundo é nada". Portanto, Mészáros procura enfatizar a oposição que haveria entre o real afirmado ante "o pleno reconhecimento da objetividade do real em sua exata dadidade" e o seu ultrapassamento pela consciência nadificante ao mesmo tempo em que por este ato ela edifica o mundo pelo projeto existencial humano. Tal identificação entre negação e totalização do mundo teria como consequência a de que

\footnotetext{
a totalidade (o real como mundo) só pode ser identificada mediante seu "colapso", ou seja, quando o mundo surge como nada mais do que o "fundo nadificado do irreal". Assim, o mundo não é o fundamento do irreal (o imaginário) - pois isso ainda preservaria a realidade do real quando ele é elevado ao status de totalidade -, mas somente seu fundamento negado. Isso significa que, quando o imaginário constrói o real como um todo, mediante sua função negadora, o que faz surgir não é a totalidade como real, mas simplesmente uma completa "niilificação" que assume a forma de uma totalidade imaginária desarticulada que necessariamente perde sua
}

PRATES, Marcelo. Imaginação, realidade e possibilidade na filosofia de Sartre. Griot : Revista de Filosofia, Amargosa/Bahia, v.17, n.1, p.154-176, junho/2018. 
totalidade na proporção direta de sua reconstituição como real. Estamos, assim, diante de uma outra "lei ontológica", ainda que desta vez não explícita, a qual postula uma razão inversa na relação entre o total e o real. O problema é, pois, não a confusão entre o total e o individual, mas sim a niilificação existencial do primeiro mediante a identificação entre "totalização" e "néantisation" (MÉSZÁROS, 2012, p. 112).

Segundo o crítico, o problema maior de tal concepção seria a negação da fusão entre positividade e negatividade por sua lei ontológica que impediria uma forma de suprassunção ${ }^{2}$. Não haveria, assim, homogeneização e objetivação da nova imagem, não elevando, consequentemente, a uma reprodução da realidade "em um nível mais alto", mas se reestabeleceria "constantemente a fragmentação da realidade" (MÉSZÁROS, 2012, p. 113) e, acrescentamos, a ineficácia da ação frente a um mundo sempre reificado, para quem a vida está muito perto das coisas ou distante por sua fragmentação. Daí que Mészáros tome como estrofe de suas críticas o problema das mediações desta totalidade.

No fundo, não por um movimento apenas de acréscimo é que teríamos depois da nadificação o mundo novamente dado, constituído positivamente pela modificação que a imaginação traria, mas seria, sim, de pressupor que o próprio mundo não chega a ser uma totalidade estática, já que a objetividade desvanece frente a nadificação constante da consciência, sendo apenas o resultado insistente desse processo e tensão constantes. Assim, o real se confunde com uma realização e essa realização com o fracasso existencial do para-si. Daí o constante sentimento de angústia que a liberdade deveria carregar. É esse sentimento de incapacidade ou de uma ação que é, mas é para nada, que a crítica de Mészáros à noção de totalidade indicava, restando apontar ainda o quão frágil eram as mediações na filosofia de Sartre para tal possibilidade.

Ora, frente a isso, como já indicamos, trata-se, antes, da ideia que o próprio Sartre quer combater e a concepção, não apenas de mundo, mas sobretudo de realidade que sua filosofia constrói. Por certo Sartre não rejeita a totalidade, e inclusive viria a associar a função do filósofo como a aquele que situa nosso tempo mediante a totalização dos saberes. Mas o que seria uma vida e uma sociedade cuja totalidade do mundo escorre por uma abertura constante, um real que escorre constantemente sobre si mesmo? Trata-se, assim, de pensar a relação entre realidade e irrealidade, e não a relação entre o fundamento e o real, mostrando que o próprio campo transcendental, sem destituir sua dimensão fáctica e, portanto, empírica, afere ao real como possibilidade e reclama para a ação, não a objetividade estática,

\footnotetext{
${ }^{2}$ Não parece ser esta a posição de Sartre a partir da dialética (CRD, p. 83) que vê que o humano também conserva para superar. No entanto, certamente isso permanece num quadro absolutamente humano. Daí que embora a Crítica pareça fornecer uma resposta, ainda assim não atenderia a esse anseio.

${ }^{3}$ Continuando o argumento: se para "agir" é preciso essa niilificação do caráter de realidade do real por uma negação genérica do mesmo, haveria a necessidade de uma segunda negação parcial ou específica. "E uma vez que a especificidade da segunda negação não pode surgir sem afetar a universalidade (a totalidade imaginária) em si, produzida mediante a negação da primeira, somos lançados de volta a um real completamente divorciado da totalidade: o mundo da fragmentação e do isolamento, da compartimentalização e da "serialização", da privatização e do confronto mortal - em uma só palavra, o mundo estéril da reificação" (MÉSZÁROS, 2012, p. 113 e 114).
}

PRATES, Marcelo. Imaginação, realidade e possibilidade na filosofia de Sartre. Griot : Revista de Filosofia, Amargosa/Bahia, v.17, n.1, p.154-176, junho/2018. 
mas a construção de seu próprio possível. É ali que encontraremos o fundamento restituído pela finitude, isto é, não o fundamento negado, mas o nada de fundamento e o real por ele erigido.

Nesse sentido, este trabalho procura averiguar esses fundamentos e procura compreender o sentido do real na filosofia de Sartre. Frente a isso será possível melhor avaliar as críticas de Mészáros e entender em que medida a própria filosofia de Sartre escapa a elas. Nossa estratégia é apontar um terceiro elemento na discussão entre o real e o imaginário, a saber, o possível. Por ele mostraremos que a tessitura do real (calcado na nadificação e na ipseidade) se compõe mais pelo possível, sobretudo a partir de $O$ Ser e o nada, que somente a relação entre real e irreal. Não é apenas por uma irrealização da consciência que o real enquanto totalidade escorre e se abre, mas enquanto possibilidade para um ser que tem de ser sua própria possibilidade. Assim, veremos mais como uma condição positiva essa totalização, que para Mészáros parece frágil, do que algo negativo que impossibilite a vida, para a qual a única saída estaria em alguma suprassunção ou mediação entre totalidades estruturadas. Por razões estritamente de foco apresentamos aqui uma tentativa de resposta e defesa do pensamento de Sartre desta segunda crítica de Mészáros, tal como a expusemos. Ademais, ela parece já apresentar, ao menos pela leitura interna de $O$ ser e o nada, o escopo de resposta às demais.

A primeira separação entre o real e o imaginário deve ser tomada ao nível da consciência. Se a consciência é o absoluto na filosofia de Sartre, é preciso lembrar que essa não é tomada no sentido estritamente husserliano, isto é, como resíduo após o procedimento da epoché. Em Sartre não há uma separação entre consciência e mundo, mas a consciência, para ser consciência, é relação imediata ao mundo. É o primeiro sentido imediato da totalidade e do real, a totalidade entre consciência e mundo, ou o ser-no-mundo. Não por menos haverá, assim, no horizonte fenomenológico, um privilégio existencial e primeiro na ordem da percepção.

Ora, desde a Introdução de O Ser e o Nada a necessidade de assegurar a transcendência ao ser do fenômeno coloca a consciência às amarras da percepção: "A percepção é o surgimento do Ser, explosão fixa e vertiginosa do Ser no "há", e é a origem para o para-si do gozo. Com efeito, na percepção é que o Ser eclode perpetuamente, é em seu olhar que se produz essa ereção vertiginosa e imóvel do Todo" (CM, 510), e ainda, "a percepção é, pois, interiorização do mundo e, num certo sentido, presença do mundo nele mesmo" (VE, p. 27). A forma da consciência como intencional ao em-si surge para dar suporte ao mundo desfazendo ao mesmo tempo a consciência de conteúdos híbridos e dando uma autonomia relativa ao mundo. Relativa porque é transcendente, mas ainda assim fenômeno, isto é, condizente à totalidade. Assim, o em-si aparece mais como aquilo que dará consistência ao mundo do que a todo e qualquer transcendente que a consciência postula enquanto ser intencional. Nesse caso, a matéria do transcendente não é una, sendo que, por exemplo, a matéria da imaginação é a própria espontaneidade da consciência, embora o realismo de Sartre será assegurado por uma única dimensão que subsumirá todas as outras formas de consciência, se distinguido da fenomenologia de Husserl e da epoqué fenomenológica como sua condição, uma vez que o em-si não será reduzido.

Esse suporte ontológico da consciência aparece apenas em O Ser e o Nada, mas a distinção entre as duas grandes formas da consciência é estabelecida já no 
Imaginário. Ali Sartre faz uma distinção entre imaginação e percepção mediante não ao estatuto da consciência, mas à matéria da consciência perceptiva e imaginante, isto é, ao modo como seu objeto é dado. Diante disso Sartre explicita os três principais modos que um objeto pode ser dado: percepção, concepção e imaginação.

Na percepção o objeto nunca é dado por inteiro, mas por perfis fugazes que se estendem a uma variação infinita (esse conteúdo infinito que Sartre mesmo acusava Husserl na Introdução de O Ser e o Nada). É essa condução ao infinito que dirigia ao novo dualismo postulado por Sartre e deste a necessidade de se apreender o ser do fenômeno, pois o objeto não é dado como síntese de todas as aparições, mas suportado por um ser que lhe fundamenta e o torna transcendente com relação à consciência. Quanto ao pensamento, a ideia é possuída inteira pela consciência uma vez que ela não possui faces, e por isso seu modo de apreensão é distinto. Ela é dada inteiramente no sentido que nem a consciência carece de algo a mais, nem a ideiaobjeto pode revelar algo a mais. Quanto à consciência imaginante ela "produz e conserva o objeto como imagem" (I, p. 28). Isso coloca o objeto como dependente da própria consciência de modo que o objeto não possui uma autonomia absoluta, e não só porque é dado por inteiro à consciência, mas porque é ela mesma que o produz, ou seja, ele é o resultado não da sua relação, mas da sua atividade; e é ela mesma que o conserva de modo que ao cessar a consciência se finda o seu objeto, diferente do que ocorre com a percepção onde seu objeto se resguarda na sua passividade e não deixa de ser mediante a alteração da atenção que recaia sobre ele. A matéria da imaginação é a espontaneidade da consciência, mas uma espontaneidade de um "grau inferior" (CABESTAN, 2004, p. 404), uma vez que ele necessitará de um aporte material exterior. Por isso seria melhor dizer que o objeto em imagem "participa da espontaneidade da consciência" (CABESTAN, 2004, p. 114), embora já tenha se desfeito da autonomia que lhe era própria enquanto espontaneidade. Por isso "o objeto como imagem não é nada mais do que a consciência que se tem. É o que nós chamamos de fenômeno de quase-observação" (I, p. 30). Quase-observação porque o objeto tematizado não é real. A imagem na medida em que é produzida pela própria consciência é posta como um nada (I, p. 28). Ser produzida e conservada dará à imagem a caraterística de objeto irreal na medida em que ela depende profundamente da consciência para existir enquanto imagem, consciência essa enraizada no mundo:

\footnotetext{
o objeto como imagem é um irreal. Sem dúvida, está presente, mas, ao mesmo tempo, está fora de alcance. Não posso tocá-lo, não posso muda-lo de lugar - ou melhor, posso sim, mas com a condição de fazê-lo irrealmente, de renunciar servir-me de minhas próprias mãos, para recorrer a mãos fantasmas que distribuirão sobre esse rosto golpes irreais: para agir sobre esses objetos irreais, é preciso que eu me desdobre, que me torne irreal. Mas, além disso, nenhum desses objetos solicita de mim nenhuma ação, nenhum comportamento. Não são pesados, nem opressivos, nem incômodos: são pura passividade, espera. A fraca vida que insuflamos neles vem de nós, de nossa espontaneidade. Se nos desviamos deles, aniquilam-se (I, p. 166, negrito meu).
}

Vindos da espontaneidade da própria consciência, eles se mantem mediante ela. Mas a postulação de tal objeto traz um prejuízo à própria consciência na medida 
em que ela sobrepõe uma atitude fantasma a essa consciência. Por estar distante, inalcançável, inalterável, esse objeto obsidia a consciência a tal ponto que ela se desdobre segundo a natureza mesma desse objeto, isto é, também ela se torne irreal, se perca do seu enraizamento enquanto ser-no-mundo, isto é, se consuma como vida imaginária. Ora, se não é o objeto que solicita tal mudança, então ela só pode ser compreendida mediante o desejo próprio da consciência, isto é, a escolha do indivíduo pela imaginação. Uma coisa é a possibilidade de imaginar, outra é a intenção com que é dirigida a construção dessa imagem. Isso traria um caráter negativo à imaginação, ainda que ela só se torne possível por ser um ato nadificador, portanto, liberdade enquanto tal. Isso porque a constituição de tal vida seria análoga a vida psíquica de modo que a atitude imaginante não passasse de uma "função particular da vida psíquica" (I, p. 162). Isso porque a vida imaginária não corresponderia apenas à imagem enquanto tal, mas "a forma de uma série de consciências imaginantes sinteticamente ligadas" (I, p. 150). É nesse ponto em que a atitude imaginante deixa de lado a sua função enquanto consciência e constitui um modo de vida, cuja irrealidade recai sobre a experiência mesma, fazendo das coisas fenômenos irreais. Não é o amor que se vive, mas o quase-amor, nem o ódio, mas o quase-ódio. A vida imaginária é esse comportamento ante o irreal, comportamento tal que ele mesmo se tornou irreal: desprendeu-se do mundo ou melhor, se obsidiou na ilusão de tal desprendimento. $O$ caráter negativo dessa forma de vida se daria pelo fato de que a vida imaginária seja uma forma com que a consciência se revela perdida ou fixada sobre seu objeto em imagem. No entanto, o modo como essa consciência se perde em seu objeto, seja como na percepção estética onde a consciência é envolvida por um interesse, seja no sonho onde ela é tomada por ele, levaria já a se supor uma passividade por conta da consciência, passividade essa que Sartre não pode admitir dada a translucidez e espontaneidade absoluta da consciência, sua negatividade infinita. A vida imaginária só pode representar uma vida inautêntica, mesmo que o ato de imaginar em si mesmo expresse ainda a liberdade, isto é, seja possibilitado por uma consciência livre que nadifica o mundo. Por isso o ato imaginário não é um ato em si inautêntico, mas a vida imaginária é consoante à vida inautêntica.

Inautêntica porque irreal, ela revela ao mesmo tempo o caráter dependente do mundo e a imaginação como atitude de degradação ante ele. Ora, sendo espontaneidade pura, portanto, nadificação, a imaginação é compreendida como "função irrealizante" (I, p. 13). Contra a ilusão da imanência, isto é, a consciência como um receptáculo que contém imagens e images-coisas, é preciso salientar que a espontaneidade sugere a consciência como atividade e sua modalidade segundo a forma dessa atividade. Por essa razão a imagem é um modo de consciência, uma relação em que a consciência "tem de se dar um objeto" (I, p. 19), sendo este irreal. Mas sendo irreal, basta que essa atividade cesse para que ele mesmo cesse. Se ele anima a espontaneidade da consciência não é por sua natureza, mas pela intenção mesma que a consciência realiza essa função. Por isso que quando Sartre diz que para que a consciência possa imaginar, segregar um nada, ela deve ser livre, é porque essa liberdade se opera sobre a condição de ser-no-mundo. Assim, essa atitude irrealizante pressupõe um refluxo com relação ao real, não se irrealiza sobre o nada, mas se irrealiza o real. A consciência, mesmo que espontânea, não cria conteúdos 
espontâneos, mas apenas na medida em que é suplantada por uma realidade. É por isso que mesmo sendo consciência há uma matéria da imagem mental: "sirvo-me de uma certa matéria que age como um analogon, como um equivalente da percepção" (I, p. 34). Nesse sentido, toda imaginação é alimentada por uma matéria que serve de analogon, seja uma matéria que é emprestada do mundo das coisas, seja do mundo mental (I, p. 37). Esse análogo como uma forma de empréstimo significa que a condição da imagem mental é irreal porque se prostra ante algo do mundo, mas feito em imagem. Assim,

não há um mundo das imagens e um mundo dos objetos. Mas todo objeto, quer se apresente à percepção, quer apareça ao sentido íntimo, é suscetível de funcionar como realidade presente ou como imagem, segundo o centro de referência escolhido. Os dois mundos, o imaginário e o real, são constituídos pelos mesmos objetos, só variam os agrupamentos e a interpretação desses objetos (I, p. 37).

Tudo o que é constituído pela imaginação é imagem, mas estas não podem ser dispostas como objetos e não apenas porque são dadas inteiramente, mas porque é o sujeito mesmo que decide sobre essa imagem com sua intenção imaginante. Em outras palavras, a consciência imaginante é animada pela intenção de se imaginar o real. Tudo se passa como se o mundo estivesse disposto sobre objetos finitos, variantes, e a imagem fosse recolhida em uma atitude de formação por imagem, cuja matéria é a própria consciência, mas fomentada por algo análogo no mundo. "O análogon é, portanto, a matéria mesma, mas animada e, nessa medida, representante do objeto" (MOUTINHO, 1995, p. 121). Ora, essa matéria é animada por uma forma de saber que passa a ser "a estrutura ativa da imagem" (I, p. 83), pois "uma imagem não pode existir sem um saber que a constitua" (I, p. 84). Dado que não é um objeto do mundo, passivo e inesgotável, "a matéria não era jamais o análogo perfeito do objeto a representar: um certo saber vinha interpretá-la e preencher suas lacunas" (I, p. 76). É ele quem visa o objeto e forma a intenção própria para além da matéria que o analogon fornece. Isto é, anima-se certa matéria para fazer nascer a representação de um objeto ausente ou inexistente. Portanto, se o mundo imaginário constituído por estes objetos irreais que compõe a vida imaginária são apenas análogos ao mundo real, se eles são animados por um saber e se mantém mediante uma escolha, esse mundo imaginário não se constitui de fato como mundo: "Quando falamos mundo dos objetos irreais, estamos empregando por comodidade uma expressão inexata. Um mundo é um todo ligado, no qual cada objeto tem seu lugar determinado e mantém relações com os outros objetos". (I, p. 175). Ora, as características do objeto irreal são determinadas justamente pela possibilidade que eles têm de formar um mundo e é nessa possibilidade que objeto existente e objeto inexistente, real e irreal se mostram absolutamente distintos. É o que Sartre assevera aferindo que o mundo implica uma "dupla condição" para seu objeto: "é preciso que sejam rigorosamente individuados: é preciso que estejam em equilíbrio com um meio" (I, p. 175). 
Sartre estabelece em $O$ Imaginário uma forma de individuação que será revogada em $O$ Ser e o $\mathrm{Nada}^{4}$. Na primeira obra a individuação do objeto aparece como prerrogativa necessária para que o mundo seja mundo. A passividade do objeto é assegurada não por um ser do fenômeno, mas por sua individuação. Ainda não há na obra uma reflexão sobre a constituição do mundo, não ao menos com toda a envergadura que terá em $O$ ser e o nada, mas apenas da sua estrutura necessária tomada como um fato exigido pelo estatuto da percepção, isto é, do objeto percebido e individualizado. Diante disso, é mais por sua distinção referente à imagem do que à sua constituição própria que o objeto percebido é explicitado.

A imagem formará uma representação cuja característica é de uma generalidade inócua, portanto, “eles não são individuados. Neles há demasiado e não há o bastante" (I, p. 175). Demasiado porque "são vários em um" no sentido de serem "equívocos" e isso não porque apresentam uma riqueza de conteúdo, mas porque carregam em si inúmeras contradições, pois "um objeto enquanto imagem não é nunca de maneira franca ele próprio" (I, p. 175). Essa generalidade não traz uma constituição certa, de modo que tal como no ego o objeto, mesmo dado em sua inteireza, não deixe de ser duvidoso, pois a imagem na sua variação já se torna absolutamente outra, o que faz com que a generalidade seja vazia e não haja enriquecimento por esta variação. Mesmo se todas as variações mostram imagens certas e absolutas elas são incomensuráveis e na sua generalidade é que se torna manifesta tais contradições:

Assim, posso produzir à vontade - ou quase - o objeto irreal que eu quero, mas não posso fazer dele o que eu quiser. Se quiser transformá-lo será necessário criar de fato outros objetos; e, entre uns e outros, forçosamente surgirão buracos. Vem daí o caráter descontínuo, intermitente do objeto enquanto imagem: ele aparece, desaparece, volta e já não é mais o mesmo; está imóvel, e em vão tento dar-lhe um movimento." (I, p. 178)

Por ser uma generalidade e não uma individualidade o objeto em imagem traz consigo essas ausências reais, cuja falta faz com que não haja "o bastante para que constitua uma individualidade rigorosa" (I, p. 175). Isso significa que mesmo numa imagem generalizada a imagem é “dispersão”. Sendo constituídos da espontaneidade da consciência, mas em um "grau menor", sendo transcendentes à consciência, mas não passivos a ponto de serem individualizados, o mundo imaginário é constituído por objetos "ambíguos, pobres e secos ao mesmo tempo, aparecendo e desaparecendo bruscamente, dão-se como um perpétuo "em outra parte", como uma evasão perpétua". (I, p. 179). Evasão do mundo, seu análogo, evasão da consciência, seu

\footnotetext{
${ }^{4}$ Retomamos tal ideia em $O$ ser e o nada na ênfase de Bernet (2002, p. 32 e 33): "Sartre conhece ao menos duas formas de um tal princípio interior de unificação e individuação: a temporalidade e o corpo próprio. Mas como ele se obstina a querer deduzir o corpo próprio da natureza da consciência, resta apenas um princípio de individuação da consciência, a saber, a temporalidade e, mais particularmente, a facticidade, cujo o corpo não é mais que uma expressão entre outros. Com efeito, há apenas a auto-temporalização da consciência finita para assegurar conjuntamente a individuação e a unificação da consciência. É, portanto, uma temporalidade composta de passado e de presente, de facticidade e ruptura, de antecipação e de um futuro imprevisível que faz da consciência um nada singular".
}

PRATES, Marcelo. Imaginação, realidade e possibilidade na filosofia de Sartre. Griot : Revista de Filosofia, Amargosa/Bahia, v.17, n.1, p.154-176, junho/2018. 
suporte material, a consciência imaginante, primeiramente livre, pode se perder no seu objeto constituído como mundo e vida imaginária:

\begin{abstract}
a evasão para qual nos convidam não é apenas a que nos faria fugir da nossa condição atual, de nossas preocupações, de nossos tédios; eles oferecem uma escapada a todo tipo de constrangimento do mundo, parecem apresentar-se como uma negação de estar no mundo, como um antimundo (I, p. 179).
\end{abstract}

Por essa negação absoluta do mundo o objeto individuado é assumido como aquilo ao qual não há negação primeira, mas ele mesmo tem que ser dado primeiramente para ser negado. Por isso os objetos em imagem "escapam ao princípio de individuação" (I, p. 175), embora Sartre mesmo não diga o que é esse princípio e como ocorre tal individuação. Isso porque a imaginação é uma nadificação, mas com relação ao dado e não como nadificação primeira como constituição do dado. Isso só será resolvido em O Ser e o Nada onde o há como determinação negativa da consciência é um fato primeiro, ato ontológico pelo qual a negatividade dá ao mundo a característica de mundo. Assim, o objeto em imagem é uma generalidade de um objeto já individuado que serve como analogon e vem animado por algum saber. "O objeto [em imagem] não é individuado: eis aqui uma primeira razão para que o irreal não se constitua como o mundo" (I, p. 179). Nesse caso, mesmo que se constitua uma vida imaginária, ela é suplantada pela vida real, seja qual for a intenção com que a imagem mesma é animada.

A segunda condição requeria não apenas a individuação do objeto, mas a necessidade de equilíbrio entre eles, como a forma de um meio, isto é, um tempo e espaço comum, ainda que relativo. Quanto a isso, o objeto irreal "ao trazer consigo seu tempo e seu espaço, apresenta-se sem nenhuma solidariedade com outro objeto [...] não age sobre nada, nada age sobre ele" (I, p. 179). Essa incomensurabilidade impossibilita um tempo comum e um espaço comum. Se na percepção há uma distância natural no sentido de que há relação entre os objetos individualizados, por sua vez, o objeto em imagem oferece um abismo entre uma imagem e outra. $\mathrm{O}$ espaço na imagem é intrínseco ao objeto irreal e não uma característica relacional. Do mesmo modo os objetos irreais são "intemporais", não comportam qualquer determinação temporal (I, p 171). Não há passado nem futuro para a imagem: "o tempo dos objetos irreais é também irreal. Não tem nenhuma característica do tempo da percepção: ele não transcorre [...] é uma sombra do tempo" (I, p. 174). Assim, sem relação imediata de um para com outro objeto, sem relação temporal que denote modificação intrínseca entre eles, os objetos irreais apenas formam um mundo irreal, ou melhor, um anti-mundo. "E por isso que não há mundo irreal, pois nenhum objeto irreal preenche essa dupla condição" (I, p. 175).

Diante disso, há um privilégio da percepção com relação à imaginação porque apenas essa forma de consciência se apresenta como forma primeira da consciência. Assim, a consciência irrefletida é condição para as outras formas de consciência, de modo que apenas ela corresponde à lei de ser da consciência. No Imaginário não há ainda o estatuto do transcendente, senão a exigência de que este apareça individualizado. Em O Ser e o Nada o em-si não é o objeto individualizado, mas toda condição para que o individualizado seja passivo e transcendente com relação à 
consciência. A individuação mesma será o resultado da relação entre as regiões transfenomenais e a determinação um nada com relação ao ser do objeto, isto é, seu sentido. Mas a totalidade mundo é dada no imediato pela consciência irrefletida. Daí que só na percepção há de fato mundo e, nesse sentido, se pudesse haver redução fenomenológica seria apenas com relação aos demais modos de consciência, no sentido de que ela não reenviaria à consciência absoluta, mas à consciência irrefletida, a consciência enraizada no mundo. É nesse sentido que Butler (2011, p. 146) acusava Sartre de um positivismo com relação à exterioridade e a realidade, donde se segue o privilégio da percepção.

Apenas a percepção "coloca seu objeto como existente" (I, p. 26). Mas, na linha interpretativa de $O$ Ser e o nada, colocar como existente não é produzir o objeto, tal como a imagem, mas desvelá-lo. Por ser inexistente ou ausente "a imagem mental é sempre constituída, jamais desvelada" (MOUILLIE, 2000, p. 108). Por isso o desvelamento da percepção estabelece a constituição do próprio real, pois "a percepção é o surgimento do Ser, explosão fixa e vertiginosa do Ser no "há"”" (CM, p. 510). A explosão do real como irrupção do nada do ser, ato ontológico, constitui a consciência irrefletida e dá o privilégio à percepção. Por isso, contra a riqueza do objeto perceptivo Sartre assevera uma "pobreza essencial" (I, p. 31) da imagem. Há no objeto percebido um "coeficiente de profundidade" do objeto (I, p. 169), há no objeto "infinitamente mais do que podemos ver" (I, p. 22). Por um lado, a individualidade do objeto permite que ele seja independente da consciência, por outro, essa independência dá a ele uma profundidade própria que o objeto irreal, como espontaneidade de grau menor, não consegue ter. Nesse caso o mundo real é o único possível para viver, e se o mundo imaginário se configura como um antimundo, então a vida imaginária deveria ser considerara uma anti-vida ${ }^{5}$. Se a vida é um movimento histórico, então "a imagem não ensina nada, não dá jamais a impressão do novo, não revela jamais uma face do objeto. Ela oferece-se em bloco. Nenhum risco, nenhuma espera: uma certeza" (I, p. 23). Por isso é chamado de fenômeno de quase-observação, pois é uma observação que não ensina nada. Nela o para-si permanece o mesmo não apenas porque a consciência é dada e constitui seu próprio objeto, mas porque não modifica o mundo nem é por ele modificada, isto é, a facticidade se perde enquanto facticidade, a finitude se demarca não por uma singularidade real, mas pelo padecimento ambíguo da consciência por ela mesma, para a qual o mundo ficou para trás e a consciência irrefletida é destituída de sua realidade ou a percepção de sua raiz mundana. Assim,

o ato de imaginação, como acabamos de ver, é um ato mágico. É um encantamento destinado a fazer aparecer o objeto no qual pensamos, a coisa que desejamos, de modo que dela possamos tomar posse. Nesse ato,

\footnotetext{
5 Isso não significa que ela seja algo a ser evitado, mas simplesmente que ela pode ou não ser constituinte de uma vida na medida em que é escolhida, seja como fuga de uma situação difícil, seja pelo simples experimento de transgressão do real. Em todo caso, fazendo parte de uma vida, ela se solidifica como ser que escolhi ser, fazendo, portanto, parte e possibilidade com que a vida se singulariza. Mas na medida em que ofusca a raiz fáctica da consciência, ela perde sua referência do real. É por este mote que Sartre explicará os problemas e variações psíquicas como a alucinação e o sonho, por exemplo.
}

PRATES, Marcelo. Imaginação, realidade e possibilidade na filosofia de Sartre. Griot : Revista de Filosofia, Amargosa/Bahia, v.17, n.1, p.154-176, junho/2018. 
há sempre algo de imperioso e infantil, uma recusa de dar conta da distância, das dificuldades (I, p. 165).

Da função irrealizante à constituição de uma forma de vida, a imaginação se torna uma linha entre a liberdade e a perdição, como se a tentativa de aprofundamento do imaginário fosse um aprofundamento irreal, uma irrealização da consciência até o limite da sua equivocidade, onde ela se perderia ante o irreal. Isso explicaria casos como os de Flaubert onde a fuga para o imaginário parece impossibilitar a própria vida real, ou onde o real recai com tal força que se torna impossível qualquer ação ou construção pela nadificação. Aqui a nadificação parece um ar nulo que mal toca no mundo, e a irrealização do real parece ser apenas a aceitação da sua força invencível, para o qual a vida imaginária é tomada pela impossibilidade de vivê-lo. É por isso que Butler enfatiza essa condição de exterioridade do real:

As vezes Sartre trata como se o domínio da exterioridade fosse o lugar único da realidade, e como se a consciência fosse uma intencionalidade transparente que poderia imediatamente revelar o ser-em-si. Segundo essa concepção, os objetos da experiência são dados positivos da experiência e a consciência não tem nenhum papel na constituição de sua existência ou significação (p. 142 e 143)

Visto dessa forma, parece que assentar a liberdade na possibilidade de imaginar não traz uma força maior a este ato enquanto ato que desfigura a totalidade do mundo ou mesmo a força maior e até única de estremecimento das estruturas. Ele precisa ser uma negação que enraíza a facticidade que lhe compõe. Se a tese realista de $O$ ser e o nada é que o ser da consciência se reduz em seu fazer-se ser (EN, p. 521) é porque a consciência não é mas se faz. Nesse sentido é que Sartre procura constantemente demarcar essa força da liberdade e as condições que impedem a consciência de se afirmar ante o real não apenas através da possibilidade de imaginação, mas com a intenção afirmativa e imperiosa da consciência nadificadora. É por isso que o real não pode nem ser concebido com o mundo estático e totalidade fechada, nem o para-si como uma potência nadificadora no outro lado do abismo, tomando o mundo em imagem. Ele precisa integrar imediatamente este mundo ao mesmo tempo que resguarda sua distância. Sabemos que essa distância que mantem a unidade é a intencionalidade. Mas ela afere também o movimento comum entre consciência e mundo como realidade:

Realizo um projeto na medida que lhe dou ser, mas realizo também minha
situação na medida que a vivencio, que a faço ser como meu ser; "realizo"
a grandiosidade de uma catástrofe, a dificuldade de um empreendimento.
Conhecer é realizar nos dois sentidos do termo. É fazer com que haja ser
tendo de ser a negação refletida deste ser: o real é realização.
Denominaremos transcendência essa negação interna e realizante que,
determinando o para-si em seu ser, desvela o em-si (EN, p. 216).

Mas, assim, se exige que com isso se realize a própria consciência, de modo que ela não seja apenas essa "negação refletida" que escorre sobre o mundo sem alterá-lo, isto é, é preciso que ela se modifique com o mundo, uma vez que ela é essa totalidade 
sintética com o mundo. Ora, a realidade da consciência depende dela na medida em que é absoluta, mas isso não é apenas um ato de existir independente ou plenamente, mas, ao contrário, para ser a consciência exige que ela seja esse fazer, do contrário ela deixa de ser essa espontaneidade, pois para ela "o fazer sustenta o ser" (EN, p. 97). Todavia, fica difícil entender o que significa este realizar-se e o fazer-se para uma consciência que é pura negatividade embora esta seja sinteticamente ligada ao mundo.

Observe-se, a consciência não poderia se realizar como ser (o caso do Ego), nem se realizar sinteticamente com o ser (o caso do em-si-para-si). No primeiro caso, o sujeito psíquico permanece fora da consciência, portanto, a constituição de um ego não é a constituição de uma consciência, que permanece sempre a mesma. No segundo caso o em-si-para-si corresponde ao valor intrínseco da consciência, que é condição dele e não algo apreendido teticamente, pois aparece como uma "indicação transcendente de uma estrutura ideal do objeto" (EN, p. 230), como aquilo que devo ser e, não obstante, não posso ser. Por isso que Sartre associa essa tentativa de realização à brincadeira: "ele brinca de ser garçom de café [...] o garçom de café brinca com sua condição para realizá-la" (EN, p. 94). Isso porque como demarcará Sartre, "não há medida comum entre o ser da condição e o meu" (EN, p. 95). O que se manifesta como ser-garçom é sempre como realização transcendente que na unidade do tempo cria a ilusão da unidade como meu ser, isto é, quando apreender-se ou é uma síntese do passado ou é uma síntese psíquica. Por isso as condições de se levantar cedo, varrer o chão, preparar os utensílios faz de toda encenação apenas uma

\footnotetext{
"representação" para os outros e para mim, o que significa que só posso sêla em representação. Mas, precisamente, se eu me represento, já não o sou, eu estou separado da condição tal como o objeto do sujeito; separado por nada, mas um nada que dela me isola, que me impede de ser, apenas julgar sê-la, ou seja, imaginar que a sou (EN, p. 95 - negrito meu).
}

Isso não significa dizer que a realização se faz pelo imaginário, mas que se faz de modo análogo a ele, com a diferença de que aqui os irrealizáveis são reais ${ }^{7}$ e não irreais (EN, p. 572). O que se tenta não é se irrealizar mediante a condição (fuga pelo imaginário), mas justamente realizá-la, isto é, “o que eu tento realizar é um ser-em-si

\footnotetext{
${ }^{6}$ É deste modo que se pode dizer que se estabelece a diferença ontológica em Sartre, não sobre a diferença entre ser e ente, mas entre ser e nada: "A diferença ontológica entre a consciência e o mundo é uma diferença entre tipos de objetos. De fato, a consciência não é um objeto, mas antes a possibilidade de apresentação dos objetos [...] A diferença ontológica entre a consciência e o mundo é a diferença entre ser e nada" (BUTLER, 2011, p. 134). Mas vale lembrar que o ser nunca é apenas objeto, mas sempre situação, por isso que nos Diários ele salienta: "Minha observação de ontem sobre os irrealizáveis presta-se a confusão. Aquilo que é irrealizável nunca é um objeto. É uma situaçãa" (DGE, p. 448 - negrito meu).

${ }^{7}$ Sobre isso é significativo os comentários nos Diários: "A arte é um dos meios que possuímos para fazer realizar vivamente e "imaginariamente", por outros, os nossos irrealizáveis. Aproveito a ocasião para observar que os irrealizáveis não são em absoluta da mesma natureza que os imaginários. São reais, estão por toda parte, mas fora do alcance. Outros podem alcançá-lo na forma realizante ou na forma imaginária. Mas a autenticidade, eu penso, tende a marcar o lugar deles à nossa volta, como irrealizáveis. Não é preciso negá-los, nem procurar em vão realizá-los, e sim assumi-los como irrealizáveis" (DGE, p. 436).
}

PRATES, Marcelo. Imaginação, realidade e possibilidade na filosofia de Sartre. Griot : Revista de Filosofia, Amargosa/Bahia, v.17, n.1, p.154-176, junho/2018. 
do garçom do café" (EN, p 94), ou seja, fazer da realização a posse de uma identidade, fazer de meu deslizar nadificador um ser real enquanto total. Mas o que ocorre é esse refluxo no qual o que se revela é a negatividade da consciência, isto é, "sendo o que não sou". Se o fazer sustenta o ser, esse ser reflete esse fazer na medida mesma que se faz, mas de modo algum traz alguma inércia à consciência. (EN, p. 96). O ser escapa na sua condição de realização: “o ser-em-si da tristeza infesta perpetuamente minha consciência (de) ser triste, mas como valor que não posso realizar, como um sentido regulador de minha tristeza, e não como sua modalidade constitutiva" (EN, p. 96). Por isso, se realizar para consciência não significa se constituir como ser, mas apenas representar, encenar, com a diferença de que se trata de uma representação real, de um esforço que reflete no transcendente e só é inteligível por ele. $\mathrm{O}$ mundo aparece como correlato real do meu desejo de ser e desaparece na medida em que a situação deixou de ser tal, em que ela fica para trás e o esforço se converte no momento atual como nova situação. Daí o desespero e a alegria dessa consciência que é nada.

Essa discrepância alude à separação que se dá entre consciência irrefletida e reflexão. É esta que objetifica o fluxo da vivência e dá a ele um caráter estático daquilo que é vivido e compreendido, mas não tematizado, por isso, para usar um outro exemplo, “o sofrimento de que falamos jamais é exatamente aquele que sentimos" (EN, p.127). Na reflexão totalizamos um acontecimento passado ou uma consciência na sua unidade com o mundo em seu caráter estático, damos uma imagem fechada a ele, mas, como dirá mais tarde Sartre, é-nos impossível apreender nossa própria totalização, ela é um movimento que enquanto vivido sempre está nos escapando, por isso jamais captamos essa totalidade enquanto vivemos, posto que no ato, voltando ao exemplo, a consciência "se nadifica como em-si pelo mesmo ato que se fundamenta. Escapa como sofrimento rumo a consciência de sofrer" (EN, p. 129). Assim, o objeto não aparece também absoluto, mas perturbado (troublée) pela vivencia da consciência. Eles são um todo nesse momento, mas um todo impossível de captar seu total sentido, já que ele escorre sem parar; por isto, em toda tentativa de vivê-lo,

só encontro a mim mesmo; eu, que lamento e gemo; eu que devo, para realizar este sofrimento que sou, representar sem trégua a farsa de sofrer. Agito os braços, grito, para que seres em-si - sons, gestos, circulem pelo mundo, conduzidos pelo sofrimento em-si que não posso ser (EN, p. $128-$ grifo meu).

Ora, o que deveríamos, então, delegar ao real enquanto realização? Veja-se que nesse momento Sartre está pensando, sobretudo a realização enquanto fundamentação, isto é, sob a miragem ontológica do $\mathrm{Si}$. O que se procura realizar aqui é a fundamentação como bloco de identidade na distância, isto é, o em-si-para-si, o termo final da suprassunção da ação e com ela a passagem da contingência à necessidade (CM, p. 159). Tal fundamentação enquanto aspecto constitutivo da realidade humana permanecerá determinando em $O$ ser e o nada e abandonado 
sobretudo a partir da Crítica ${ }^{8}$. Não obstante, a tensão ontológica faz permanecer essa imagem da discrepância entre ser e nada e o real como resultado dessa tensão.

Diante disso, tudo o que o indivíduo faz se refere a um movimento direcionado ao mundo, mas sem ele mesmo corresponder a esse movimento. Ser garçom é uma condição do mundo, uma realização do mundo, de uma situação e não de constituição da consciência. Se esse ser garçom aparece como uma ausência e um irrealizável, então disso se segue uma separação entre vida e realização. Esta última, não pertencendo à vida espontânea, coadunando com a vida exterior da consciência, na medida em que esta apenas reflete, mas se mantem apenas como horizonte psíquico do Ego, a vida é uma realização fracassada, uma irrealização real, donde, então, o imaginário permanece também um esforço de realização radicalizada por esta impossibilidade de ser, e não apenas como uma desrealização do mundo, dada sua dificuldade ${ }^{9}$.

Certamente isso recai sobre a ideia de existência, pois na medida em que estamos "rodeados ao infinito" (EN, p. 572) por estes irrealizáveis, eles são o conjunto que denota o homem particular e, por isso, são por ele assumidos como escolha de ser. Ser garçom nada mais é que minha escolha de ser garçom, estar triste nada mais é que minha escolha da tristeza; escolho ser a minha situação, me faço tal singularidade pela minha escolha. Mas desde que há uma separação entre consciência e mundo onde a consciência aparece "como um irreal em busca (quête) ativa de realidade" (BUTLER, 2011, p. 134), essas "irritantes ausências" (EN, p. 572) que pululam a vida do indivíduo e lhe dão o ar de suas escolhas, compreendem a sua vida como impossível, sem peso. Por isso que Sartre, referindo-se a Beauvoir que teria denotado em um de seus romances esta ideia, disse que esses irrealizáveis são tais quais "a "aventura" que foge sempre do aventureiro em meio às conjunturas mais extraordinárias, mas que é uma categoria essencial da ação humana. Em A náusea pareço afirmar que ela não existe. Mas é errado. É melhor dizer que é um irrealizável" (DGE, p. 436). Se tal aventura é impossível, então se recai na exterioridade da contingência e vemos o para-si alheio ao mundo, como um deus brincalhão que age sem ser afetado por suas ações, senão pelo riso irônico que ela provoca. Parece que damos jus às críticas de Mészáros tomando a teoria nesse tom.

Todavia, é preciso compreender, dado o problema do real, a ordem das razões. Se tomamos o dualismo entre o ser e a consciência parece que sempre nos

\footnotetext{
${ }^{8}$ Veja-se: "A alienação fundamental não vem, como $O$ Ser e o Nada, poderia fazer crer, por engano, de uma escolha pré-natal: mas da relação unívoca de interioridade que une o homem como organismo prático a seu meio ambiente" (CRD, p. 225 - nota 55, negrito meu). Acerca disso Simont (1998, p. 133) discorre: É esta ininteligibilidade inerente a escolha original de si como livre ou como alienada que se encontra suprimida na Crítica. Que o homem se projete rumo a esta ambição de "síntese" que é o em-si-para-si, não é mais como em $\mathrm{O}$ Ser e o Nada, o resultado de uma misteriosa escolha original - de uma "escolha pré-natal", diz a Crítica -, mas o da simples estruturação material da relação do organismo com o ambiente" (negrito meu).

9 Algo análogo ocorre com o fenômeno da emoção. Ela seria uma atitude ante o mundo difícil, que impossibilitando a vivência nele, se torna fator pelo qual a consciência se precipita, transformando-se por inteiro, isto é, degradando-se (ETE, p. 78), de modo que não apenas projeta esse drama, mas o vive; enfim: "Ela busca conferir ao objeto, por ela mesma e sem modificá-lo em sua estrutura real, uma outra qualidade, uma menor existência ou uma menor presença (ou uma maior existência, etc.). Em suma, na emoção é o corpo que, dirigido pela consciência, muda suas relações com o mundo para que o mundo mude suas qualidades" (ETE, p. 65)
}

PRATES, Marcelo. Imaginação, realidade e possibilidade na filosofia de Sartre. Griot : Revista de Filosofia, Amargosa/Bahia, v.17, n.1, p.154-176, junho/2018. 
depararemos ante a impossibilidade de coadunação dessas duas instâncias como realidade, pois se a consciência é nadificação, translucidez e fluxo constante, então, para ela, realizar-se deveria ser manter essa nadificação mesma, de modo que ela, assim, não se realizaria senão como irreal, como puro nada, isto não, não chegaria a ser. Se o mundo só pode se revelar como um "complexo de utensílios" com "tarefas a realizar", ou seja, como "mundo de tarefas" (EN, p. 236), a consciência aparece apenas como o reflexo que alteraria o mundo sem se alterar, e se o ser é a totalidade e se o real é realização, então ele não realizaria nada: o real permanece irrealizável. Parecia assim, que haveria sempre uma dessincronia no real, pois ora o para-si se perde no imaginário, ora no mundo, e quando entregue a si estaria sempre frente a sua angústia nadificadora, pois mesmo transformando o mundo, permanece distante dele. Isso porque para a consciência a realização, aqui, corresponderia à finalização desse próprio fazer, à suspensão da nadificação pela consolidação dela como ser. Isso seria recair na mesma impossibilidade do em-si-para-si, seria recair na anti-dialética dos princípios. Por isso é necessário que a consciência se coadune a essa realização, que a realização do mundo seja a realização da consciência. É na tentativa de escapar a isso que Silva mostra que o que define de fato a consciência não é sua condição realizadora, mas sua condição de possibilidade,

\begin{abstract}
Por mais paradoxal que possa parecer, o que o para-si tem de real refere-se muito mais ao possível do que ao realizado. Ora, o possível é aquilo que ainda não é real: e o conhecimento do para-si refere-se ao que não é real na medida mesma em que a condição humana de diáspora faz com que a realidade humana esteja exatamente ali onde não a encontramos: na possibilidade de sua realização [...] Isso requer que pensemos na vida do para-si como a efetuação de possibilidade mais do que como realização de possibilidades (SILVA, 2003, p. 45).
\end{abstract}

Em O ser e o nada Sartre postula o possível como uma estrutura imediata da consciência, portanto, a consciência é sua própria possibilidade: “O possível surge como fundo de nadificação do para-si" (EN, p. 133). Nesse sentido, não é que algo seja possível ao para-si, como nadificar-se, ou desprender-se do mundo, mas surgir como para-si é ser "projetado para seus possíveis próprios" (EN, p. 133). Não no sentido de que há uma possibilidade para o ser, ou que o nada capta ou é conduzido a este segundo uma possibilidade também exterior. Tomando a tese da nadificação como fenômeno enquanto aparecimento do nada no cerne mesmo do ser, e a nadificação como ocorrência no ser, tudo se passa como se o nada fosse "a possibilidade própria do ser e sua única possibilidade" (EN, p. 115). Nesse sentido, o ser que é, só pode se possibilizar mediante sua nadificação, o que nos termos da fenomenologia de Sartre quer dizer que "a captação do possível como tal pressupõe um transcender original" (EN, p. 136).

Ora, sabemos por esta fenomenologia que reclama a dupla dimensão transfenomenal que a única transcendência é aquela da imanência de si a si pela qual o ser se faz anunciar o que é na sua tentativa de fundamentação, tal é a paixão do ser ou o seu sentido para-si. É por isso que Sartre diz que isso só pode ocorrer no ser mediante sua possiblidade interna, isto é, o possível "só pode vir ao mundo por um ser que é sua própria possibilidade" (EN, p. 136). Por isso que o possível é considerado como "novo aspecto da nadificação do para-si" (EN, p. 136), de modo 
que não há nadificação que não implique seu possível. Ora, é claro que é possível para a consciência a imaginação e mesmo a concepção. No entanto, como a imaginação mesma pressupõe a consciência irrefletida com seu enraizamento no mundo, e como a possibilidade pressupõe um "transcender original", a real possibilidade do para-si é dada na sua ligação imediata com o mundo. É por isso que, uma vez que o para-si é sua facticidade e esta se apresenta não apenas como aquilo ao qual não posso não ser, mas, sobretudo, aquilo a partir do qual eu vou me determinar a ser, a ipseidade aparece como "a relação do para-si com seu possível que ele é" (EN, p 139), cuja consequência é a determinação do "mundo" como "a totalidade de ser na medida em que é atravessada pelo circuito de ipseidade" (EN, p. 139), isto é, o mundo é determinado pela relação do para-si com seus possíveis.

É essa relação imediata da ipseidade com o mundo que faz do possível não a impossível falta a ser preenchida, embora seja assumida em sua estrutura a condição de que "a realidade humana existe como privação-totalidade, ou melhor, como falta e, concomitantemente, como ligação sintética imediata com aquilo que lhe falta" (BORNHEIM, 2003, p. 59), mas é justamente por conta de sua "indigência ontológica, ele é movimento de totalização infinita" (RIZK, 2011, p. 80). Todavia, ele não se resume nesta negatividade, ou melhor, esta negatividade não pode ser vista como uma forma de paralização pelo desespero, pelo contrário, ela é o próprio ímpeto da ação. Por isso a ação é sempre positiva embora seja ontologicamente fundamentada pela nadificação. $O$ que se tem nesse jogo é, como alude Rizk (2011, p. 88) que toda aparição do mundo é sempre também questão sobre si mesmo na subjetividade. Por isso não há uma adequação plena entre esses dois processos totalizadores a ponto de uma síntese por uma suprassunção. $O$ para-si em seu processo é ao mesmo tempo sua possibilização enquanto questão em seu próprio ser na ipseidade com o mundo. Mesmo que haja um ganho qualitativo da passagem de um possível ao outro, ele é sempre mantido em suspenso pela liberdade, mas de modo algum isso deve ser confundido com uma separação entre possível e real. Como comenta Silva sobre esse processo,

\begin{abstract}
Há possibilidades "reais" de ressignificar a facticidade objetiva: a contradição entre possibilidade e realidade é superada, na sua oposição lógica, pela transcendência como processo de temporalização e historialização. Mas a transcendência histórica não é a dissolução da contradição, nem a conciliação dos opostos. Se a ação é determinada pelos obstáculos que ela supera, isso quer dizer que a história real não é constituída por oposições externas (tese e antítese em relação de completa exterioridade recíproca), mas por um processo de alteração do mesmo, no sentido de uma afirmação recíproca dos contrários, um necessitando do outro para consolidar sua identidade (2003, SILVA, p. 62)
\end{abstract}

É por isso que ela não implica nem uma condição idealista, nem realista (enquanto oposição ao idealismo). Sartre sempre procura escapar dessas duas visões. A primeira por absorver o possível "no ser subjetivo da representação" (EN, p. 134). Sartre não reduz o possível à representação ou ao cogito, pois isso o faria depender de nossa ignorância e conhecimento e, portanto, seria exterior ao ser do para-si, tal como acusa Leibniz, seja com relação aos compossíveis, e Espinosa, seja com relação à nossa ignorância sobre o necessário. Também não é a melhor solução tratar o 
possível como algo não humano, como faz a visão científica que, no fim, acaba por convertê-los "em puros resultados subjetivos de nosso cálculo lógico e nosso nãosaber" (EN, p. 135). Assim, a possibilidade não coincide com o pensamento, mas com a "estrutura objetiva dos seres ou de um ser particular" (EN, p. 135), isto é, àquele ser que é sua própria possibilidade: "O possível não é, o possível se possibiliza; na exata medida em que o para-si se faz ser, o possível determina por esboço esquemático de uma ubiquação de nada que o para-si está para além de si” (EN, p. 139). Mas a possibilização é coadunada com a própria realização. A questão sobre o ser do para-si é a questão sobre sua situação, sobre o mundo, na medida mesma que, para ser tal questão, exige a tomada de tal mundo. Em outras palavras, a realização não é o fechamento da totalidade, mas a abertura de tal processo como mundo em relação constante com sua possibilidade. Assim, "tomar o real por uma realização significa que nem o idealismo de uma constituição subjetiva, nem o realismo sólido de um real precedente são admitidos: trata-se, antes, de uma invenção infinita do mundo pela liberdade e pela ação" (RIZK, 2011, p. 88)

Deste modo, uma vez que esse processo exige a produção de si no mundo, ele afere não só a realidade, mas a uma tomada positiva dessa condição (BORNHEIM, 2003, p. 61), pois o possível aponta e exige sempre que esse movimento se desdobre no mundo, por isso ele aponta não ao mundo, mas como lembra Bornheim se referindo a $O$ ser e o nada, "à totalidade do existente no mundo" (BORNHEIM, 2003, p. 61). Em outras palavras, positivamente a vida enquanto possível ao mundo é vista como uma chance (CM, p. 505). Enquanto liberdade, há sempre uma outra chance - a totalidade voltará a fender-se. Assim sendo, não há mundo que não seja imbricado pela ipseidade, isto é, pela consciência que se anuncia por seu próprio possível. Não só a estrutura não se mantém por si, como não há mediação que não se realize senão como possibilidade do para-si.

Veja-se que isso coaduna com a ideia de realização, de modo que uma vez que são o mesmo movimento, não há uma separação entre real e possível (o que não implica que o possível seja realizado), pois como bem explicitou Silva, o que importa no possível é sua efetuação, isto é, ser posto enquanto tal. Nesse sentido, se a totalidade abrange o horizonte dos possíveis pelas quais a liberdade numa Época se desenha, observe-se que é apenas vivendo que esse horizonte é rompido, isto é, na medida em que pelo seu projeto o para-si ao se anunciar no real traz a ele uma condição nova, e isso só é possível pela condição nadificante do homem: só há liberdade quando o que não era colocado como possível é posto como nossa possibilidade mais imediata. Essa possibilidade não é outra que a estruturação do mundo mesmo, o que não implica que ele não seja adversidade uma vez que é facticidade, mas que nele, por ele, e para além dele, sejam feitos os caminhos da liberdade.

Nesse caso, a existência deveria ser medida por sua condição de possibilidade e realização como possibilização, isto é, numa condição de variação de possíveis e não por sua condição de realização efetiva; mais pela fuga de uma condição que por sua proximidade às coisas (justamente seu sentido maior de perda). Observe-se que, nesse sentido, a paixão do para-si não é a perda no mundo, deste mundo que o obsidia, a paixão é o reverso deste mundo, é para o mundo ainda por vir que o para-si se perde como liberdade. Por isso a liberdade é sempre projeto. Isto é, ela não é na medida em que se realiza, mas em que se possibiliza, em que requer sempre a si como 
possibilidade, tal como a vida autêntica que requeria para si a liberdade e a vida espontânea. Aqui a possibilização é quem dá concretude à escolha e à liberdade e sua alienação pela singularização. A realização do possível não traz a constituição à consciência, mas lança-a "com outro horizonte de possíveis" (EN, p. 138). Todavia, essa nova dimensão nadificadora, isto é, como outro possível, só é presumível porque há o reconhecimento dessa diferença como outro possível.

Isso não é uma condição unicamente da consciência enquanto ser dos possíveis, mas porque tal horizonte se manifesta na raiz da ipseidade justamente pela dimensão fáctica corporal, pois o corpo é aquilo que "está por toda parte" (EN, p. 364), fazendo referência não apenas ao organismo, mas a toda estruturação material de modo que ele se estende "sempre através da ferramenta que utiliza" (EN, p. 364). Por isso que é apreendido como um ente entre outros se tornando ele mesmo instrumento desse meio. A realização não é senão a conclusão de uma trajetória, uma "tarefa". Nesse caso a possibilidade se ergue ou enquanto esse trajeto é rompido pela liberdade por conta da mudança de tarefa ou pelo esgotamento da tarefa, sua irrealização, que concomitantemente recai num novo horizonte de possíveis. Em todo caso, se o que age é o corpo (corpo que é consciência e não um substrato material autônomo), este não pode permanecer intacto pela própria exigência da ação de realização de modo que "a estrutura do mundo subentende que só podemos nos inserir no campo de utensilidade sendo nós mesmos utensílios; que nós não podemos agir sem sermos agidos" (être agis)" (EN, p. 363). Ser agido para o corpo não pode ser somente o reflexo do curso do próprio mundo em perspectiva, isto seria fazer do corpo uma facticidade que desconhece sua condição fáctica, fazendo do corpo algo puro, portanto, tornando-o fator de sobrevoo e não de adentramento ao mundo. Assim, embora a possibilidade não indique realização, indica que as possibilizações são marcadas pela diferença do campo dos possíveis, de modo que se não há o reconhecimento de que algo ficou, então não há diferença entre a possiblidade primeira e a possibilidade segunda. Assim, o novo horizonte de possíveis deve mais que somente reconhecer o fracasso da irrealização, assumir a diferença que há entre um possível e outro e fazer dessa diferença mesma sua realidade, sua singularidade. Daí que a saída pelo imaginário não seja de toda negativa ${ }^{10}$, pois se ela recai para uma possibilização enquanto única saída quando o real já se perdeu na serialidade, ela é fator positivo de constituição dessa diferença e reabertura do campo dos possíveis. Mas o que a determina não é sua função própria, mas a situação vivida. Por isso não pode ser tomada como uma formula universal que possa dar a resposta sobre se ela se perde ou se liberta, pois é a situação que decide. Também não se pode determinar que o possível dependa desse processo, pois ele é uma estrutura imediata da consciência irrefletida e afere diretamente sobre a realidade e por isso não pode se perder como vida imaginária, pelo contrário, afere a uma necessidade de ação no mundo e no corpo para enraizar o próprio ato. Por isso que essa diferença possibilizada não é outra que a vida do indivíduo, àquilo mesmo que Mészáros

10 Além do que, como observa Butler (2011, p. 137) "Sartre procura mostrar que não somente a imaginação foi um constituinte necessário de todos os atos de conhecimento, mas que também sem a imaginação seria impossível apreender os objetos na sua 'realidade'. Nesse sentido, portanto, a imaginação é uma fonte de busca espontânea sobre as estruturas possíveis e escondidas da realidade, uma epoché do mundo existente que a consciência coloca no cerne da experiência do mundo"

PRATES, Marcelo. Imaginação, realidade e possibilidade na filosofia de Sartre. Griot : Revista de Filosofia, Amargosa/Bahia, v.17, n.1, p.154-176, junho/2018. 
acusará como uma falsa mediação. No entanto, uma vez que a possibilização é a condição mesma de totalização e, por isso, esboço de totalidade, ela não destitui a subjetividade de sua constituição (e isso não por conta de uma tese idealista como já apontamos), mas, aferimos novamente, é justamente o contrário:

é preciso que ela se engendre quase-mecanicamente, por uma alquimia do imaginário ele mesmo. Alquimia da repetição e da diferença: por tudo isso que as liberdades imaginárias consideradas possuem suficientemente obstinação, energia, elas não retornam compulsivamente em círculos no éter dos seus sonhos sem que a repetição do impasse não termine por dar lugar a uma diferença significativa, a uma solução inédita, a partir do qual, apesar deles, eles sairão deles mesmos e encontrarão uma tomada ativa sobre o mundo (SIMONT, 1998, p. 195 - negrito meu).

Nesse sentido, a imaginação adquire sua função plena de irrealização do real quando este já impede ou dificulta a sua própria possibilização. Temos aqui o inverso da pretensão metafisica, pois se esta pensava os atos de consciência como um esforço de fundamentação, vemos que, no fim, em termos práticos, a imaginação é a condição própria de uma epoché que se realiza não ante o real ou o ser, mas ante a obstrução do ser próprio do real, isto é, como possibilidade oriunda do mesmo, sobre o mesmo, contra o mesmo. É, por assim dizer, uma saída que se toma em casos de desespero (SG, p. 546). Mas o que é a liberdade senão a invenção dessa saída?

Em todo caso, é na facticidade mesma, no seu encurtamento e fechamento da liberdade, que esse ato diferencial se opera e encontra seus contornos. Ele se imprime justamente na facticidade mórbida transformando-a e enriquecendo-a. Essa congruência entre corpo e consciência, entre negatividade e estrutura se radicalizará na Crítica por causa de uma dinâmica entre éxis e práxis, de modo que a práxis não se operará sobre o mundo sem sofrer com isso. Ora, em $O$ Ser e Nada o corpo aparece como uma "relação existencial" (EN, p. 369) porque "a consciência existe seu corpo". No entanto, ele não é tomado ali na obra como o organismo que a Crítica denotará, no sentido de que há uma interiorização que condiciona o fator fático e sua práxis subsequente. Por isso que o que mais há de relevante contra apenas esse aspecto de reflexo do corpo não é tanto sua assimilação à consciência, mas à sua individuação ${ }^{11}$ e sua relação à heterogeneidade interiorizada pela consciência que, nesse caso, é também corpo, sobretudo com relação ao psíquico ${ }^{12}$. Por isso, como aponta Butler,

\footnotetext{
11 Se o mundo aparece como uma perspectiva, uma tarefa, a possibilização do para-si é o ponto de convergência dessa estrutura. Nesse sentido o corpo como fator de individualização, (EN, p. 349) representa o ponto singular da situação de cada para-si, que o coloca em perspectiva: "Sartre identifica o corpo ao limite da liberdade e a condição insuperável de individuação" (BUTLER, 2011, p 173). Individuação pelo corpo, cuja referência primordial se refere ao nascimento (EN, p. 367), é nossa condição de existência enquanto ser que temos de ser no-meio-do-mundo. Assim, ele se torna limite pelo fato de que é esse corpo que manifesta a condição fáctica da nossa escolha, ou melhor, "a necessidade de que eu não seja tudo ao mesmo tempo" (EN, p. 368).

${ }^{12}$ Com relação a isso Sartre se refere ao corpo psíquico (EN, p, 377), pois quando a consciência tende a objetivar sua "qualidade" rumo ao objeto, faz desse uma estrutura psíquica: "O movimento primeiro da reflexão é, portanto, para transcender a pura qualidade de consciência da dor rumo a um objetodor" (EN, p. 375). Esse objeto psíquico, transcendente e passivo, Sartre o designa, nesse momento, como "o mal". Mal porque ele será dotado de um animismo (EN, 376), com duração, forma e hábito próprio, vindo a surgir e agir magicamente. Mas porque é corpo também, o psíquico não aparece como
} 
Sartre não concebe a subjetividade como o resultado de uma história feita de circunstâncias, mas, antes, como a realização ou a determinação singular dessa história. $O$ indivíduo se apropria das circunstâncias históricas e biográficas e as concretiza - ou as realiza - em sua própria personalidade. Tal é o conceito de universal singular (BUTLER, 2011, p. 200 - negrito meu)

Tudo se passa como se a possibilização por ser condição nadificante se sobressaísse sempre à constituição passiva do corpo, e o cansaço, a cicatriz, a modificação corporal como um todo, fossem vistas mais como o solo fáctico e concreto pelo qual eu realizo esse ultrapassamento pela possibilização, cuja realização é o sujeito mesmo enquanto indivíduo que viveu estas coisas e que justamente por isso se constituiu como este indivíduo enquanto singularização de todo este processo ${ }^{13}$. Assim, é preciso mostrar que o corpo é mais do que a consciência "lateral e retrospectiva" (EN, p. 369) que se tem dele, que ele é mais que o "omitido", o "negligenciado", é preciso mostrar que só o corpo é, que é nele que a facticidade se resguarda como fator de passado ${ }^{14}$ e mundo, e que é ele o enraizamento do mundo, pois fora dele "o resto é nada e silêncio" (p. 370). Em suma, é o meu enraizamento no mundo como minha possibilidade. Eis o porquê seja apenas vivendo que seja possível realizar-se como possível sem que isso implique uma realização como identidade estática e fechada. Assim sendo, a possibilidade só pode ser processo de totalização, mas jamais de instituição:

Trata-se antes de uma sintetização (não de uma síntese) de dois percursos de um mesmo processo: totalizações singulares como movimentos diversos de formação da totalidade. A complexidade que afeta a descrição sartreana desse processo advém da dificuldade de se compreender a articulação das mediações entre indivíduo e totalidade sócio-histórica. Sendo o indivíduo um agente histórico, ele não pode ser considerado como uma parte; sendo a história um processo, ela não pode ser considerada como um todo. No entanto, não basta introduzir alguma dinâmica nessa relação. É preciso

um horizonte transcendente ao indivíduo, mas correlato ao seu corpo, de modo que corpo e consciência "padecem" esse mal, de modo que ele não se torna apenas uma qualidade da consciência, nem um objeto transcendente, mas a condição específica da situação vivida. Assim, "o corpo é objeto psíquico por excelência, o único objeto psíquico" (EN, p. 387).

13 Veja-se que tal processo alude ao processo histórico e ao processo singular como o mesmo processo. Daí que a síntese seja sempre o universal singular: "É preciso compreender a articulação de sentido entre a totalidade e a singularidade. Não se pode perder de vista o sentido da totalidade: isto significa, precisamente, recusar para uma totalidade um sentido absolutamente dado, já que isto equivaleria a atribuir uma significação fechada a um processo aberto. Mas se o sentido do conjunto é inseparável da forma como ela se totaliza, é preciso compreender a função que desempenham na formação as "partes" que constituem a totalidade em curso. Ora, tais "partes" são denominadas singularidades exatamente porque são capazes de totalizar. Trata-se de algo mais do que a simples relação entre o particular e o universal. $O$ evento singular totaliza singularmente a totalidade: isto significa que o sentido da totalidade não é independente destas totalizações singulares, que uma visão analítica consideraria parciais, mas que numa abordagem dialética devem ser compreendidas como totalidades dentro da totalidade. É pela totalização singular que se define o sentido da totalidade, e ao mesmo tempo a produção singular de totalidades define o processo de totalização" (SILVA, 2003, p. 58).

14 Isso porque ele é percebido como "uma perpétua e inapreensível remissão a um ser-passado" (EN, p. 388), de modo que sua quididade não é senão com relação a esse passado específico.

PRATES, Marcelo. Imaginação, realidade e possibilidade na filosofia de Sartre. Griot : Revista de Filosofia, Amargosa/Bahia, v.17, n.1, p.154-176, junho/2018. 
considerar uma reciprocidade ativa na maneira pela qual o indivíduo produz a totalidade e a totalidade produz o indivíduo. É por essa razão que nas duas instâncias deve-se falar em totalização (SILVA, 2003, p. 58).

Nesse caso, se a facticidade é estabelecida mediante suas condições práticas de passado, situação e corpo, é preciso que se considere uma imbricação mais radical ainda entre elas na medida em que os possíveis sociais são interiorizados e estruturados mediante o próprio corpo, cujo passado não é uma historialização abstrata, mas a condição mesma que eu tenho que superar pela práxis pela invenção constante dos meus possíveis próprios e deste corpo, deste passado e deste mundo como minha possibilidade mais imediata. A individualidade requer que o corpo não seja o instrumento que reflita essa negatividade num complexo de utensílios, mas que seja interiorizado e vivido mediante a escolha do indivíduo que exteriorizará aquilo antes interiorizado, do contrário ou o mundo seria sempre o mesmo, já que o para-si apenas o refletiria, ou modificado ante o acaso. Por isso que o para-si é ipseidade, onde essa relação com seus possíveis atravessa o mundo fazendo com que esse para-si não seja uma possibilidade abstrata. Por conta disto que na Crítica o possível é compreendido mediante os esquemas sociais ${ }^{15}$ (CRD, p. 79) que a práxis interioriza e modifica em seu ato. A práxis não é apenas a consciência negativa, mas um ato dialético, é a mudança nessa mesma realização, que não é um fator exterior, mas exige que o que se exterioriza traga consigo a marca finita da liberdade, isto é, a escolha singular do indivíduo como modificação de si e do mundo como sua possibilidade. Um trabalho complexo que envolve todo um campo fáctico e a constituição da relação com os possíveis como seu modo de ser. Trata-se, para voltar à ontologia, da imanência do mesmo, cujos processos singularizadores como possibilização já não podem ser medidos por sua totalidade, pois são rupturas constantes, senão por sua finitude, pela invenção singular de seus possíveis. Em outras palavras, o mesmo enquanto finito é a diferença possibilizada. Apreender o fenômeno do mundo não é tomar uma universalidade ou totalidade, mas sim esses processos de totalização e ver o próprio total em seu movimento pelo movimento mesmo das vidas que envolvem.

Se o mundo é humano, o mundo humano não é a estrutura fixa, estática. A totalização não é distinta da singularização enquanto efetuação de um possível que é a própria vida do para-si individualizado. $O$ homem também não é somente um serno-mundo, mas uma possibilidade para que o mundo seja o que é. Embora essa inércia e autonomia do mundo seja resguarda, seja pela opacidade do em-si, seja pelo prático-inerte, é sempre o homem que manter o mundo, este mundo como sua possibilidade no ser e como ocorrência própria do ser. No fundo o mundo é apenas a possibilidade que eu tenho para anunciar a mim mesmo aquilo que sou, mas uma vez que sou não só minha situação, mas vivo minha situação livremente, o mundo permanece em suspenso na liberdade do para-si. Há, assim, uma totalidade do mundo e do homem, uma realidade, mas esta é anunciada pelos meus possíveis próprios, os quais não são dados pela disposição material do mundo, mas surgem nele

15 Para um complemento: "Em O Ser e o $\mathrm{Nada}$, e mais claramente nos estudos biográficos ulteriores e na Crítica da Razão Dialética, a liberdade se encontra menos ligada aos ideais ontológicos, que transcendem a história, que ao projeto concreto e altamente mediatizado que visa a suportar, a interpretar e a reduzir uma situação socialmente complexa" (BUTLER, 2011, p.174).

PRATES, Marcelo. Imaginação, realidade e possibilidade na filosofia de Sartre. Griot : Revista de Filosofia, Amargosa/Bahia, v.17, n.1, p.154-176, junho/2018. 
mesmo pelo nada que tenho de ser. Nesse caso, o real na sua totalidade é suplantado pelo possível e não pela imaginação.

Se Mészáros criticava Sartre por fazer a determinaçãodo mundo pela negatividade e que com isso se fragmentava o mesmo, dizemos que, antes, essa fragmentação é justamente o pululamento no real pelos possíveis do para-si. São essas rachaduras a fragmentar o mundo que são o escoamento da própria realidade. Este mundo enquanto escoamento de possíveis é bem distinto daquele estruturado que Mészáros exige. Como bem enfatiza Silva, "o homem não é um império num império, mas é um processo dentro de um processo" (2003, p. 58). O mundo real não somente é uma possibilidade, mas minha possibilidade, e é por ela que ele se anuncia enquanto tal. Assim, contra a dialética do Espírito ou do Estado, no nosso plano e sem suprassunção, para nós, no ser, tudo se resolve no humano, ou melhor, na contingência do humano: "Mamie diria: Escorreguem, mortais, não queiram segurarse" (P, p. 183). 


\section{Referências bibliográficas}

BERNET, Rudolf. La 'conscience' selon Sartre comme pulsion et désir. In Alter revue de phénoménologie - Sartre phénoménologue. N $^{\circ}$ 10/2002 - editions ALTER.

BORNHEIM, G. Sartre: Metafísica e existencialismo. $3^{\text {a }}$ ed. São Paulo: Editora Perspectivas, 2003.

BUTLER, Judith. Sujets du désir - réflexions hégéliennes en France au XXe siècle. Paris: Presses universitaires de France, 2011.

CABESTAN, P. L'Être et la conscience - recherches sur la psychologia et l'ontophénoménologie sartriennes. Paris: OUSIA, 2004.

MÉSZÁROS, I. A obra de Sartre - busca da liberdade e desafio da história. São Paulo: Boitempo, 2012.

MOUILLIE, Jean-Marc. Sartre - conscience, ego et psyché. Paris: Presses Universitaires de France, 2000.

MOUTINHO, Luiz D. S. Sartre: psicologia e fenomenologia. Brasiliense, 1995.

RIZK, H. Comprendre Sartre. Paris: Armand Colin, 2011.

SARTRE, J-P. A transcendência do ego. Seguido de Consciência de si e conhecimento de si. Trad. Pedro M. S. Alves. Lisboa: Edições Colibri, 1994.

- As palavras. Rio de Janeiro: Nova Fronteira, 1984.

- Crítica da razão dialética - Tomo I: Teoria dos conjuntos práticos, precedido por Questão de método. Tradução: Guilherme João de Freitas Teixeira. Rio de Janeiro: DP\&A, 2002.

. Cahiers por une morale. France: Gallimard, 1983.

. Diário de uma guerra estranha. Rio de Janeiro: Nova Fronteira, 2005.

. Esboço para uma teoria das emoções. Porto Alegre: L\&PM, 2007.

L'être et le néant - essai d'ontologie phénoménologuique. France:

Gallimard, 2007. [O ser e o nada. Tradução: Paulo Perdigão. 12. ed. Petrópolis - RJ: Vozes, 2003.]

. O imaginário - psicologia fenomenológica da imaginação. São Paulo:

Editora ática, 1996.

. Saint Genet - ator e mártir. Petrópolis, RJ: Vozes, 2002.

- Verdade e existência. Tradução: Marcos Bagno. Rio de Janeiro: Nova

Fronteira, 1990.

SILVA, F. L. e. Conhecimento e identidade histórica em Sartre. Trans/Form/Ação,

São Paulo, 26(2): 43-64, 2003. Disponível em: http://www2.marilia.unesp.br/revistas/index.php/transformacao/article/view/854. Acesso em: 01/02/2018.

SIMONT, Juliette. Jean-Paul Sartre : un demi-siècle de liberté. Paris, Bruxelles : De Boeck \& Larcier s.a., 1998. (imprimé en Belgique) (le point philosophique Collection dirigée par Daniel Giovannangeli).

Autor(a) para correspondência: Marcelo Prates, Universidade Estadual do Centro-Oeste, R. Salvatore Renna, 875 - Santa Cruz, CEP 85015-430, Guarapuava - PR, Brasil.marceloprates1@gmail.com

PRATES, Marcelo. Imaginação, realidade e possibilidade na filosofia de Sartre. Griot : Revista de Filosofia, Amargosa/Bahia, v.17, n.1, p.154-176, junho/2018. 